\title{
Cervical Cancer Clinical Distant Metastasis TNM Finding v7
}

National Cancer Institute

\section{Source}

National Cancer Institute. Cervical Cancer Clinical Distant Metastasis TNM Finding v7.

NCl Thesaurus. Code C89500.

A clinical finding about one or more characteristics of cervical cancer, following the rules of the TNM AJCC V7 classification system as they pertain to distant metastases. 